\title{
MENINGKATKAN PEMAHAMAN KOSAKATA BAHASA INGGRIS MELALUI METODE PERMAINAN BINGO
}

\author{
Hana Nurwahidah Sudrajat \& Herlina \\ e-mail: hanandrah@gmail.com \\ PGSD Universitas Negeri Jakarta \\ JI. Taman Setia Budi II No.1, RT.2/RW.2, Daerah Khusus Ibukota Jakarta 12910
}

\begin{abstract}
Abstrak: Penelitian ini bertujuan untuk mengetahui apakah pemahaman kosakata bahasa Inggris dapat ditingkatkan melalui penerapan metode permainan bingo pada siswa kelas III SDS Laboratorium PGSD Setiabudi FIP UNJ Jakarta Selatan. Penelitian ini adalah penelitian tindakan kelas yang dilaksanakan dalam 2 siklus menurut model Kemmis dan McTaggart. Subjek dalam penelitian ini adalah siswa kelas III SDS Laboratorium PGSD Setiabudi FIP UNJ. Pengumpulan data dilakukan menggunakan instrumen tes untuk mengukur pemahaman kosakata bahasa Inggris siswa dan lembar pengamatan untuk menilai efektifitas proses penerapan metode permainan bingo yang meliputi aktivitas guru dan siswa. Instrumen diuji secara validitas dan realibilitas. Hasil yang diperoleh dari penelitian ini yaitu adanya peningkatan yang signifikan pada perolehan skor pemahaman kosakata bahasa Inggris siswa setelah penerapan metode permainan Bingo..
\end{abstract}

Kata kunci: pemahaman, kosakata, permainan Bingo.

\section{IMPROVING OF THE MASTERY OF ENGLISH VOCABULARY THROUGH BINGO GAME}

\begin{abstract}
The objective of this research is to investigate whether the implementation of Bingo game can increase students' mastery of English vocabulary at the 3rd grade students of Primary School of PGSD Laboratorium in Setiabudi South Jakarta. Using the model of Kemmis and McTaggart, this classroom action research was conducted in two cycles. The subject of this research were 20 students of the 3rd grade and the data were collected using test instrument to measure students'level of vocabulary mastery. The observation sheet was also used to record the activities of the teacher and the students when they were playing bingo game. The result of this research shows a significant increase in vocabulary mastery score after the application of Bingo game.
\end{abstract}

Keywords : mastery, vacabulary, Bingo game.

\section{PENDAHULUAN}

Bahasa merupakan alat komunikasi yang memegang peranan penting dalam kehidupan. Dengan menggunakan bahasa, seseorang dapat berinteraksi dengan manusia lain, mengekspresikan diri, mengungkapkan perasaan, menyampaikan ide, informasi maupun gagasan serta menyebarluaskan ilmu pengetahuan. Bahkan, melalui ragam bahasa tulis maupun lisan, bahasa dapat berperan menjadi pengantar yang paling efektif dan efisien dalam dunia pendidikan. Kemampuan dan keterampilan berbahasa dapat dilatih dan kemampuan dan keterampilan berbahasa memiliki peran penting dalam dikembangkan secara berkesinambungan dengan pembinaan sedini mungkin. Karena mengembangkan aspek-aspek kognitif, afektif dan psikomotorik sebagai penunjang keberhasilan siswa di masa yang akan datang.

Pendidikan Bahasa Inggris di SD/MI dimaksudkan untuk mengembangkan kemampuan berbahasa yang digunakan untuk menyertai tindakan atau language accompanying action. Bahasa Inggris digunakan untuk interaksi dan bersifat here and now. Topik pembicaraannya berkisar pada hal-hal yang ada dalam konteks situasi. Untuk mencapai kompetensi ini, peserta didik perlu diajarkan dan dibiasakan dengan berbagai ragam pasangan bersanding (adjacency pairs) yang merupakan dasar menuju kemampuan berinteraksi yang lebih kompleks.

Dalam Kurikulum Tingkat Satuan Pendidikan 2006 mata pelajaran bahasa Inggris di SD/MI 
bertujuan agar peserta didik memiliki kemampuan (1) mengembangkan kompetensi berkomunikasi dalam bentuk lisan secara terbatas untuk mengiringi tindakan (language accompanying action) dalam konteks sekolah, (2) memiliki kesadaran tentang hakikat dan pentingnya bahasa Inggris untuk meningkatkan daya saing bangsa dalam masyarakat global. Selain itu, ruang lingkup mata pelajaran Bahasa Inggris di SD/MI mencakup kemampuan berkomunikasi lisan secara terbatas dalam konteks sekolah, yang meliputi aspek-aspek sebagai berikut: (1) mendengarkan, (2) berbicara, (3) membaca, 4) menulis.

Kesulitan siswa kelas III SD Laboratorium PGSD FIP UNJ pada pelajaran bahasa Inggris khususnya pada pemahaman kosakata (vocabulary) umumnya disebabkan karena siswa masih banyak yang belum berani menjawab pertanyaan di depan kelas dan terlihat masih banyak mengajukan pertanyaan saat diberi penugasan akibat ketidakpahaman siswa akan berbagai kosakata bahasa Inggris. Akibatnya, keadaan dan situasi kelas menjadi tidak kondusif sehingga tujuan agar siswa memahami berbagai kosakata bahasa Inggris pun tidak maksimal. Penggunaan metode pembelajaran yang masih bersifat konvensional memiliki dampak secara langsung maupun tidak langsung dalam mempengaruhi minat dan partisipasi siswa dalam proses pembelajaran.

Pada metode permainan, dapat ditemukan berbagai jenis aktivitas permainan yang dapat diterapkan di dalam proses pembelajaran. Permainan kosakata bahasa Inggris atau vocabulary games bingo merupakan cara potensial untuk membuat pembelajaran kosakata bahasa Inggris siswa menjadi lebih bermakna. Penerapan permainan bingo dapat mengelaborasi kemampuan pemahaman kosakata siswa yang menjadi dasar ilmu dalam pembelajaran bahasa Inggris. Pengaplikasian permainan bingo pun dapat pula disesuaikan pula dengan kebutuhan dan kemampuan siswa.

Permainan bingo pada dasarnya merupakan metode belajar bagi para siswa yang seringkali bertanya tentang arti dari berbagai kosakata (vocabulary) pada guru, tujuannya ialah agar siswa lebih memahami kosakata bahasa Inggris secara mandiri. Melalui permainan bingo pula, siswa dapat memahami kosakata bahasa Inggris dengan cara yang menyenangkan dan sederhana. Dari sekian banyak tipe permainan bingo untuk meningkatkan pemahaman kosakata (vocabulary) siswa, Pictionary Words Bingo merupakan tipe permainan bingo yang paling baik dan cocok diterapkan pada pembelajaran bahasa Inggris di sekolah dasar.

Kosakata (vocabulary) dalam pembelajaran bahasa, termasuk bahasa Inggris, merupakan salah satu hal yang penting untuk dikuasai. Kosakata dapat diartikan sebagai kumpulan kata-kata yang dipahami oleh seseorang. Seseorang yang memahami kosakata dengan baik akan berdampak pula pada proses komunikasi yang baik (Nunan, 2006). Pendapat lain menyebutkan vocabulary adalah kumpulan kosakata yang biasa digunakan untuk berkomunikasi bagi semua orang (Bamhart, 2008). Seseorang akan lebih mudah memahami suatu bahasa (berkomunikasi) apabila terlebih dahulu memahami arti dari kosakata yang digunakan.

Terdapat empat cara untuk memahami kosakata, yakni (a) form, (b) pronunciation, (c) word meaning, dan (d) usage (Brewster, Ellis \&Girard, 2003). Form adalah mempelajari: (a) listening and repeating, (b) listening for specific phonological information (consonant, vowel sounds, sumber syllable, stress pattern), (c) looking at or observing the written for shape, first and last letters, letters clusters, spelling, (d) noticing grammatical information, and 5) copying and organizing. pronunciation merupakan pengucapan atau pelafalan. Word meaning yaitu mempelajari arti kosakata (vocabulary) dan bagaimana hubungannya dengan konsep materi serta kosakata (vocabulary) lainnya. Usage adalah mempelajari bagaimana penggunaan kosakata (vocabulary) itu sendiri.

Pemahaman kosakata yang berkaitan dengan ranah kognitif yang terdiri atas kemampuan remember (C1), understand (C2), apply (C3), analyze (C4), evaluate (C5), dan create (C6) (Anderson \& Karthwohl, 2001). Hal ini dapat dijelaskan bahwa "remember (mengingat)" merupakan kemampuan seseorang menghasilkan informasi yang tepat dari ingatan. Remember (mengingat) terdiri dari dua unsur: (a) recognizing (mengenali), yaitu memperkenalkan pada siswa suatu konsep, ide atau gagasan yang belum pernah ia temui dan pelajari sebelumnya; dan (b) recalling (mengingat kembali), yaitu membantu siswa mengingat kembali konsep, ide dan gagasan yang pernah ditemukan atau pelajari.

Understand (memahami) merupakan kemampuan seseorang untuk mengartikan atau memaknai informasi dari berbagai materi ajar atau pengalaman. Kemampuan understand (memahami) terdiri dari tujuh unsur: (a) interpreting (menafsirkan), (b) exemplifying (memberi contoh), (c) classifying, (d) 
summarizing, (e) inferring (menduga), (f) comparing (membandingkan), dan (g) explaining (menjelaskan) adalah kemampuan merumuskan dan menjelaskan hubungan sebab-akibat.

Apply (menerapkan) merupakan kemampuan seseorang untuk menerapkan suatu prosedur. Apply dibagi menjadi excecuting dan implementing. Excecuting (melakukan) yaitu siswa dihadapkan pada soal yang familiar atau apa yang dilakukan untuk melengkapi soal itu, sedangkan implementing (mengimplementasikan) yaitu mengimplementasikan informasi yang dimiliki. Analyze (menganalisis) merupakan kemampuan seseorang untuk memecahkan sebuah konsep menjadi beberapa bagian dan menjelaskan bagaimana bagian-bagian tersebut saling berhubungan atau berkaitan satu sama lain.

Analyze (menganalisis) terbagi menjadi tiga unsur yakni, differentiating (membedakan) yaitu kemampuan membedakan bagian-bagian dari keseluruhan struktur dalam bentuk yang sesuai, organizing (mengorganisasi) yaitu kemampuan mengidentifikasi unsur-unsur secara bersama-sama menjadi struktur yang saling terkait dan attributing (memberi simbol) yaitu kemampuan siswa untuk menyebutkan tentang sudut pandang, nilai atau maksud dari suatu masalah yang diajukan. Attributing membutuhkan pengetahuan dasar yang lebih agar dapat menerka maksud dari inti permasalahan yang diajukan.

Evaluate (mengevaluasi) merupakan kemampuan seseorang untuk membuat penilaian berdasarkan standar dan kriteria melalui checking (pemeriksaan) dan critiquing (mengkritisi). Create (menciptakan) merupakan kemampuan seseorang untuk meletakkan bagian-bagian pecahan secara bersama-sama untuk membentuk sesuatu yang baru atau mengenali berbagai komponen dari sebuah struktur yang baru.

Secara sederhana pembelajaran kosakata dapat dilakukan melalui empat tahap. Pertama, introducing: guru memperkenalkan kata baru dengan ucapan dan pelafalan yang jelas dan benar, gunakan media gambar atau benda nyata. Kedua, modelling: guru memberi contoh dengan bertindak sebagai model. Ketiga, practicing: guru melatih siswa untuk menirukan dan berlatih. Keempat, applying: siswa menerapkan dalam situasi yang tepat dengan bantuan guru (Suyanto, 2010)

Hal yang menyenangkan bagi anak, terutama siswa sekolah dasar adalah bermain, karena dunia anak tidak lepas dari bermain. Anak-anak yang masih berusia sekolah dasar pasti membutuhkan sarana hiburan untuk mengekspresikan diri setelah belajar. Permainan merupakan kebutuhan alami yang muncul dalam setiap individu. Permainan dapat membangkitkan rasa senang dan antusias dalam diri seseorang. Menurut pengertiannya, permainan adalah situasi atau kondisi tertentu saat seseorang mencari kesenangan atau kepuasan melalui suatu aktivitas atau kegiatan bermain. Dengan bermain, siswa akan memperoleh suatu kegembiraan, kepuasan, rasa antusias, pengalaman yang berbeda dan bermakna hingga terbentuk berbagai keterampilan dalam dirinya.

Prensky (2001) mengemukakan bahwa play has a deep biological, evolutionarily important, function, which has to do specifically with learning. 1) Games are a form of fun. 2) Games are form of play. 3) Games have rules. 4) Games have goals. That gives us motivation. 5) Games are interactive. 6) Games are adaptive. 7) Games have outcomes and feedback. 8) Games have win states. 9) Games have conflict/competition/challenge/opposition. 10) Games have problem solving. 11) Games have interaction. 12) Games have representation and story.

Finch (2006) berpendapat Bingo has the potential to make foreign language vocabulary learning interesting, challenging, student-centered, and collaborative. Pendapat lain menyebutkan bahwa ide dasar permainan bingo adalah untuk mendorong siswa belajar dan mengulang kembali pelajaran kosakata tersebut (Richardson, Morgan dan Kimberly, 2014). Kimberly lebih lanjut mengatakan bahwa bingo kosakata adalah permainan yang dapat dimainkan oleh seluruh siswa di kelas atau terbagi menjadi kelompok-kelompok kecil. Guru dapat menjadi The Caller atau si pembaca soal, namun tidak menutup kemungkinan bahwa siswa dapat menjadi The Caller atau si pembaca soal. The Caller bertugas untuk membacakan pertanyaan-pertanyaan berkaitan dengan materi ajar tentang kosakata yang dipelajari.

Bingo menurut Buttner ( 2013) adalah suatu permainan lama yang menjadi favorit dalam kelas bahasa asing. Papan bingo tradisional mempunyai kata bingo yang dieja di atas kolom-kolomnya, dan semua kotak bingo yang berjumlah 25 masing-masing berisi satu angka. Murid mendengarkan angka yang diucapkan dalam bahasa sasaran dan meletakkan sebuah kepingan di kotak berisi angka yang mereka dengar. Murid harus mendapatkan lima kotak yang 
berderet secara vertikal, horizontal atau diagonal.

Bingo pada dasarnya merupakan permainan sederhana yang memberikan kesempatan bagi para pemainnya untuk mendengar dan mencari informasi sederhana (menjawab soal pertanyaan) dan menandainya pada papan permainan masingmasing tanpa mengubah informasi atau menggunakan kemampuan kognitif seperti pemecahan masalah, berpikir kritis, dan lain sebagainya.

Pemain yang mampu menjawab soal dengan tepat dan menandai papan bingo menggunakan alat tulis secara horizontal, vertikal atau diagonal sebanyak lima kotak berturut-turut serta meneriakkan kata "Bingo!" setelahnya akan menjadi pemenang dalam permainan. Wikipedia (2012) , menyebutkan pengertian bingo adalah a game of chance played with different randomly drawn numbers which players match against numbers that have been pre-printed on $5 \times 5$ cards. Many versions conclude the game when the first person achieves a specified pattern from the drawn numbers. The winner is usually required to call out the word "Bingo!", which alerts the other players and caller of a possible win.

Ningtias (2014), menyederhanakan pengertian permainan bingo sekaligus menjelaskan tata cara permainan ini agar dapat diaplikasikan pada pembelajaran bahasa asing di kelas yaitu: First students can make bingo cards to divide a piece of paper into five rows and five columns or four rows and four columns (depending on the command of the teacher) with one free space box where students can determine the position of their free space box. The students can create questions and answers in another paper that is given to the caller (the person who read about). All vocabularies and definitions are written on strips of paper and put in a container. Caller pulls the strip from the container, then read the definition; check the word from the list. They will write the correct answer according to the column of numbers or objects that definition read out by the caller. The first student to get bingo wins the game.

Klasifikasi dari berbagai variasi tipe permainan bingo ini dapat digunakan dalam berbagai situasi dan transformasi. Bingo dapat digunakan melalui satu tipe ke tipe lain sesuai dengan tujuan pembelajaran yang ingin dicapai. Tipe bingo yang digunakan disesuaikan pula dengan karakteristik siswa (usia, kemampuan kognitif, afektif dan psikomotorik). Melalui cara ini diharapkan permainan bingo dapat disesuaikan dengan baik untuk memenuhi kebutuhan siswa.

\section{METODE PENELITIAN}

Metode penelitian adalah action research bertujuan untuk memperbaiki dan meningkatkan hasil belajar siswa dengan menggunakan metode bingo dalam proses pembelajaran agar lebih efektif dan efisien. Desain intervensi tindakan atau rancangan siklus penelitian ini menggunakan Model Kemmis dan McTaggart. Adapun prosedur kerja dalam penelitian ini melalui 4 tahapan yang dilalui, yaitu (1) perencanaan, (2) pelaksanaan, (3) pengamatan dan (4) refleksi, seperti yang disajikan pada gambar 1.

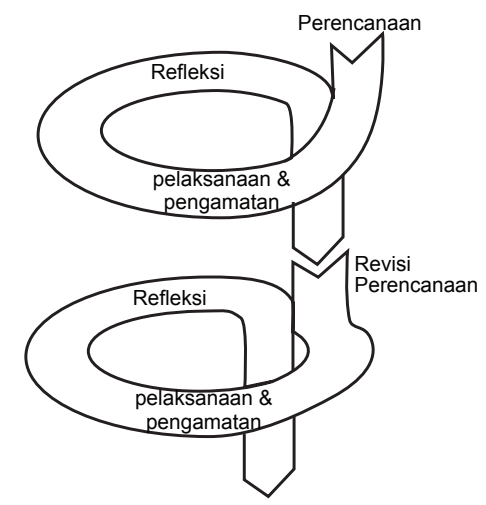

Gambar 1. Prosedur penelitian berdasarkan model Kemmis dan McTaggart.
Penelitian dilakukan pada bulan Maret - Juni 2015 di SD Laboratorium PGSD FIP UNJ Jakarta Selatan. Subjek yang terlibat dalam penelitian ini adalah siswa/i kelas III yang berjumlah 20 siswa/i, yang terdiri dari 14 siswa laki-laki dan 6 siswi perempuan. Partisipan dalam tindakan ini adalah guru bahasa Inggris yang terlibat sebagai observer yang mengetahui situasi kelas serta memahami bahasa Inggris dan secara kolaboratif dapat membantu dalam penelitian ini. Data yang digunakan pada penelitian ini terdiri dari dua jenis yaitu data pemantau tindakan dan data penelitian. Data pemantau tindakan merupakan data yang digunakan untuk mengontrol kesesuaian pelaksanaan metode permainan bingo untuk meningkatkan pemahaman kosakata bahasa Inggris siswa dengan rencana (planning) yang telah dibuat dan disusun oleh peneliti.

Sumber data pemantau tindakan diperoleh dari hasil pengamatan pada lembar observasi tentang pelaksanaan metode permainan bingo. Bertujuan untuk melihat dan mengetahui aktivitas siswa saat proses pembelajaran berlangsung. Sumber data hasil penelitian diperoleh dari hasil tes evaluasi setiap siklus 
untuk mengukur sejauh mana pemahaman kosakata bahasa Inggris siswa.

Analisis data dilakukan pada setiap kegiatan refleksi, yaitu berupa tanya jawab dan diskusi antara peneliti tindakan dengan pengamat. Data yang dianalisis berupa hasil evaluasi siswa dalam setiap akhir siklus, hasil instrumen pemantau tindakan yang telah diisi dan catatan lapangan dari pengamat.
Analisis data yang akan digunakan pada penelitian ini adalah menganalisis lalu kemudian membandingkan pemahaman kosakata (vocabulary) siswa pada setiap siklusnya, dan membandingkan pemahaman kosakata (vocabulary) siswa pada kegiatan awal pembelajaran dan akhir penelitian. Setelah itu, peneliti akan menyimpulkan apakah terjadi peningkatan atau tidak setelah tindakan dilakukan.

\section{HASIL DAN PEMBAHASAN}

\section{Hasil Penelitian}

Data dalam penelitian ini diperoleh dari 20 siswa kelas III SD Laboratorium PGSD FIP UNJ Jakarta Selatan dalam dua siklus penelitian. Data yang diperoleh ada dua, yakni, data tentang pemahaman kosakata bahasa Inggris siswa dan data pemantau tindakan kelas dengan menggunakan metode permainan bingo.

Pada siklus I, mayoritas siswa belum terlihat memahami kosakata bahasa Inggris materi clothes sehingga membutuhkan bimbingan dan bantuan guru pada saat menjawab kartu soal pertanyaan permainan bingo, soal latihan dan soal evaluasi akhir siklus. Data yang diperoleh dari pemahaman kosakata siklus I disajikan pada tabel 1.

Tabel 1. Perolehan Nilai Pemahaman Kosakata Siswa Pada Siklus I

\begin{tabular}{cc}
\hline NILAI & JUMLAH SISWA \\
\hline 60 & 4 \\
65 & 3 \\
70 & 5 \\
75 & 4 \\
80 & 4 \\
\hline Jumlah & 20 \\
\hline
\end{tabular}

Data pada tabel 1 menunjukkan bahwa dari 20 siswa yang mendapat nilai di bawah 70 sebanyak 7 siswa dan yang mendapatkan nilai $\geq 70$ sebanyak 13 siswa. Maka hasil persentase pemahaman kosakata bahasa Inggris siswa pada siklus I mencapai $65 \%$, sedangkan hasil instrumen pemantau tindakan sebesar $60 \%$. Berdasarkan refleksi dan analisis data pada siklus I, hasil siswa dalam pemahaman kosakata bahasa Inggris belum mencapai target yang ditetapkan (80\%) sehingga penelitian dilanjutkan ke sikus II.

Pada siklus II, siswa sudah terlihat memahami kosakata bahasa Inggris karena repetisi atau pengulangan materi yang guru lakukan baik pada saat proses pembelajaran menggunakan metode permainan bingo, soal latihan maupun soal evaluasi. Siswa pun dapat mengerjakan soal tanpa bantuan atau bimbingan guru. Data yang diperoleh dari pemahaman kosakata siklus II disajikan pada tabel 2.

Tabel 2. Perolehan Nilai Pemahaman Kosakata Siswa Pada Siklus II

\begin{tabular}{cc}
\hline NILAI & JUMLAH SISWA \\
\hline 65 & 1 \\
70 & 2 \\
75 & - \\
80 & 1 \\
85 & 1 \\
90 & 5 \\
95 & 3 \\
100 & 7 \\
\hline Jumlah & 20 \\
\hline
\end{tabular}

Data tabel 2 menunjukkan adanya peningkatan yang signifikan dari tabel sebelumnya. Siswa yang mendapatkan nilai 65 atau nilai di bawah 70 sebanyak 1 orang, sedangkan siswa yang mendapatkan nilai $\geq 70$ sebanyak 19 orang siswa.

Berdasarkan refleksi dan analisis data pada siklus II, ternyata hasil pemahaman kosakata bahasa Inggris siswa sudah mencapai target yang ditetapkan yaitu $95 \%$ dari target persentase yang ditetapkan yaitu $80 \%$. Sementara hasil instrumen pemantau tindakan sebesar $85 \%$ dari target yang ditetapkan yaitu $80 \%$.

Pencapaian persentase hasil pemahaman kosakata bahasa Inggris siswa pada siklus I sebesar $65 \%$ dan siklus II sebesar 95\%, maka tindakan pada siklus II ini dihentikan dan dianggap berhasil karena telah melampaui target persentase yang telah ditetapkan sebelumnya yakni $80 \%$ dari seluruh siswa yang mencapai nilai pemahaman kosakata bahasa 
Inggris $\geq 70$. Sementara itu, hasil pemantau tindakan pada siklus I sebesar $60 \%$ dan siklus II sebesar $85 \%$ dari target persentase yang telah ditetapkan sebesar $80 \%$.

Berdasarkan data pada tabel 1 dan 2, maka dapat disimpulkan bahwa persentase penguasaan kosakata bahasa Inggris siswa dari siklus I ke siklus Il telah mencapai $\geq 80 \%$ jumlah siswa yang mencapai skor $\geq 70$ dan telah mengalami peningkatan sebesar $30 \%$. Sementara itu, untuk data hasil pemantau tindakan aktivitas guru dan siswa pada siklus I sebesar $60 \%$ dan siklus II sebesar $85 \%$, mengalami peningkatan sebesar $25 \%$.

\section{Pembahasan}

Hasil analisis yang telah dilakukan terhadap data awal dari siklus I sampai dengan siklus II menunjukkan adanya peningkatan pemahaman kosakata bahasa Inggris siswa menggunakan metode permainan bingo. Berdasarkan interpretasi hasil analisis tersebut, maka dapat disimpulkan adanya peningkatan pemahaman kosakata bahasa Inggris dari siklus I dengan persentase $65 \%$ dan siklus II dengan persentase 95\%. Dengan demikian tindakan perbaikan dianggap tidak perlu lagi dilakukan dalam pelaksanaan tindakan selanjutnya.

Sesuai dengan data analisis yang telah dijelaskan di atas, maka metode permainan bingo dapat diterapkan pada pembelajaran kosakata. Dalam proses pembelajaran ini siswa dilatih untuk menjawab soal-soal pertanyaan dengan cepat dan tepat lalu menuliskan jawaban pada papan tulis sehingga siswa dapat menguasai dengan baik kosakata yang dipelajarinya. Mayoritas siswa telah berani maju ke depan kelas untuk menjawab dan menulis jawaban mereka di papan tulis. Mulanya, siswa kesulitan menulis kosakata dalam bahasa Inggris, akan tetapi dengan adanya repetisi jenis soal yang diberikan guru pada saat permainan bingo, siswa semakin ahli untuk menguasai kosakata, terutama pada materi clothes. Melalui permainan bingo yang dilaksanakan secara berkelompok pula, siswa dapat saling membantu antar teman untuk mengetahui dan memahami lebih banyak kosakata bahasa Inggris yang tengah dipelajari. Siswa yang telah diperkenalkan sebelumnya dengan kosakata materi clothes berikut dengan gambargambarnya serta menjawab soal-soal pertanyaan pada permainan bingo pada akhirnya menanamkan pemahaman pada diri masing-masing siswa.

Selain itu melalui latihan soal terus-menerus dari siklus I sampai dengan siklus II, pemahaman kosakata bahasa Inggris siswa semakin meningkat. Berdasarkan hasil analisis data penelitian tindakan kelas di atas, menunjukkan bahwa penggunaan metode permainan bingo dapat dipilih sebagai alternatif dalam meningkatkan pemahaman kosakata bahasa Inggris siswa di kelas III sekolah dasar

Berdasarkan analisis data dalam proses pembelajaran pada tahap pelaksanaan siklus I. Mulanya, guru memperkenalkan berbagai kosakata materi clothes pada siswa melalui bantuan gambar sekaligus memperkenalkan pula kalimat Simple Present Tense pada siswa. Selanjutnya, guru mengajak siswa bermain permainan bingo dengan membagi siswa menjadi 4 kelompok. Dalam 1 kelompok terdapat 5 orang siswa yang telah guru sesuaikan tingkat kemampuannya. Akan tetapi, dalam pelaksanaannya, guru tidak menjelaskan dengan detail tata cara dan aturan utama permainan bingo serta tidak menerapkan aturan keseluruhan saat terjadinya proses pembelajaran, sehingga keadaan kelas menjadi tidak kondusif, serta pada permainan bingo pertemuan pertama di siklus I tidak memperoleh pemenang. Selain itu, saat pelaksanaan tes evaluasi akhir siklus, banyak siswa yang belum memahami kosakata yang telah diajarkan sebelumnya dan tidak mengetahui maksud dari sebagian butir soal yang terdiri dari 4 jenis soal berbeda.

Hasil tes evaluasi yang dilakukan oleh 20 orang siswa dalam pemahaman kosakata bahasa Inggris menunjukkan bahwa ada 13 orang siswa yang mendapatkan nilai tertinggi atau telah mencapai nilai di atas $\geq 70$. Umumnya siswa yang telah mendapatkan nilai 80 adalah siswa yang berprestasi di sekolah dan selalu berpartisipasi aktif dalam proses pembelajaran. Akan tetapi, siswa yang mendapatkan nilai $\geq 70$, salah satunya seperti $M$ yang memperoleh nilai 60 diakibatkan oleh siswa yang pasif dalam proses pembelajaran dan enggan untuk mempelajari lebih lanjut materi yang belum dipahami. M cenderung asal-asalan saat menjawab soal-soal pertanyaan dan tidak bersemangat ketika mengikuti proses pembelajaran.

Saat guru melakukan pendekatan pada M untuk menanyakan sebab kurangnya semangat M pada saat belajar, M mengaku malas dan tidak bisa dalam pembelajaran bahasa Inggris. Menurut observer atau pengamat, keseharian $M$ saat proses pembelajaran berlangsung, $M$ cenderung 
sulit memahami materi dengan cepat, khususnya dalam pembelajaran bahasa Inggris, sehingga guru berinisiatif untuk memberikan perhatian lebih pada siswa yang kurang cepat memahami materi pada siklus ke II.

Pada siklus ke II, setelah peneliti berdiskusi dengan pengamat, akhirnya peneliti memutuskan untuk memperbaiki tindakan yang masih kurang atau belum dilakukan. Seperti pendalaman materi, soalsoal pertanyaan yang terus diulangi, dan menunjuk setiap siswa untuk menjawab soal-soal pertanyaan, khususnya yang belum memahami materi dengan baik. Guru pun menerapkan aturan dan melibatkan observer dalam proses pembelajaran, khususnya pada saat permainan bingo berlangsung sehingga siswa relatif lebih tertib dan siswa yang belum memahami materi dapat lebih diperhatikan dan dibimbing oleh guru. Pada pertemuan kedua di siklus II ini dilakukan evaluasi berupa 20 butir soal dengan 4 jenis soal yang berbeda. Siswa tampak senang dan cermat dalam mengerjakan karena telah terlatih sebelumnya saat proses pembelajaran menggunakan metode permainan bingo.

Pada tes pemahaman kosakata bahasa Inggris siswa pada siklus II menunjukkan hasil yang jauh lebih baik bila dibandingkan dengan tes pemahaman kosakata bahasa Inggris pada siklus I. Hasil yang memuaskan tercapai pada 19 orang dari 20 orang siswa. Hanya 1 orang yang mendapatkan nilai $\geq 70$. Beberapa siswa yang pada siklus I hanya mendapatkan nilai 70 dapat membuktikan kemampuan pemahaman mereka sehingga perolehan hasil nilai meningkat. Sayangnya, siswa $\mathrm{M}$ hanya mendapatkan nilai 65 dari nilai 60 dari yang didapatkan pada siklus sebelumnya, sehingga masih belum mampu mencapai batas nilai $\geq 70$. Padahal, pada pelaksanaan permainan bingo, guru telah memberikan kesempatan pada $\mathrm{M}$ dan meminta teman sekelompoknya untuk membantu, akan tetapi hasil nilai akhir pada siklus II masih belum meningkat sesuai yang diharapkan.

Pada setiap pertemuan di siklus I dan II dilakukan pengamatan oleh observer yaitu guru bahasa Inggris kelas III SD Laboratorium PGSD FIP UNJ Jakarta Selatan dengan mengisi instrumen pemantau tindakan berupa 20 butir pernyataan. Selain itu, pada setiap akhir siklus peneliti dan pengamat melakukan refleksi. Pada refleksi siklus I ditemukan beberapa kekurangan, antara lain: siswa yang mendapatkan giliran menjadi The Caller atau pembaca soal belum merata, dari setiap kelompok, hanya segelintir siswa yang mampu dan berani menjawab setiap soal pertanyaan, kurang tertibnya siswa dalam proses pembelajaran dan beberapa siswa yang duduk di bangku belakang. kurang mendapatkan pengawasan dan perhatian. Namun, kekurangan dan kelehaman tersebut sudah diperbaiki di siklus II.

\section{PENUTUP}

Berdasarkan hasil penelitian yang dilakukan, peneliti menyimpulkan bahwa penelitian tindakan kelas sangat berperan bagi seorang pengajar untuk dapat mengetahui seberapa besar kemampuan siswa dalam menguasai dan memahami materi, khususnya kosakata bahasa Inggris yang dipelajari. Hal tersebut dapat dilihat melalui dua tahapan yang peneliti lakukan dalam pelaksanaan pembelajaraan yaitu terlihat tingkat keberhasilan siswa pada siklus I memperoleh persentase sebesar $65 \%$, kemudian pada siklus II mencapai $95 \%$. Peningkatan pada siklus II tersebut sudah melampaui target yang telah ditetapkan oleh peneliti yaitu $80 \%$. Sementara itu, persentase data hasil pemantau tindakan pada siklus I adalah $60 \%$, meningkat pada siklus II menjadi $85 \%$. Jadi, dapat disimpulkan bahwa metode permainan bingo dapat diterapkan untuk meningkatkan pemahaman kosakata bahasa Inggris siswa.

\section{DAFTAR PUSTAKA}

Anderson, L. W.,\& Nunan, D. R. A Taxonomy for Learning, Teaching, and Assesing: A Revision of Bloom's Taxonomy Educational Objectives. Dikutip dari http:// thesecondprinciple.com/ teaching-essentials/beyond-bloom-cognitivetaxonomy-revised/ yang diakses pada tanggal 7 Desember 2015, pukul 22.56

Bamhart, C. A. (2008). The Facts On File Student's Dictionary of American English. New York:
Facts of File, Inc.

Brewster, J. Ellis G, \& Girard D. (2003). The Primary English Teacher's Guide. London: Penguin English.

Finch, A. (2006). Meaningful vocabulary learning: interactive bingo. 2006. Taiwan: Kyungpook National University.

Ningtias, P. A. (2014). The effect of bingo game in teaching vocabulary at the first grade of SMA 
YP UNILA. Journal Research of Universitas Lampung. Diakses dari http://digilib.unila. ac.id/5937/ pada tanggal 22 Desember 2015, pukul 6.47

Nunan, D. (2006). Practical english language teaching: young learners. New York: McGrawHill Companies, Inc.
Prensky, M. (2001). Fun, play and games: what makes games engaging. Digital game-based learning. USA: McGraw-Hill.

Suyanto, K. K. E. (2010). English for young learners. Jakarta: Bumi Aksara.

Wikipedia. Bingo games. Diakses dari https:// en.wikipedia.org/ wiki/Bingo_(U.S.) pada tanggal 11 Desember 2015 pukul 05.00 